\title{
Special Issue \\ Standards and Competency Frameworks for School Administrators: \\ Global, Comparative and Critical Perspectives
}

education policy analysis

\section{archives}

A peer-reviewed, independent, open access, multilingual journal

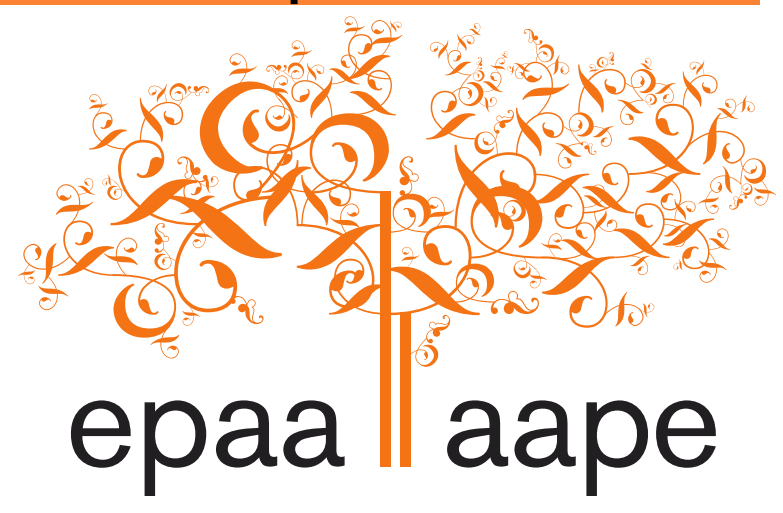

Arizona State University

\section{The Development of Competencies Required for School Principals in Quebec: Adequacy Between Competency Standard and Practice}

\author{
Monique Lambert \\ do \\ Yamina Bouchamma \\ Université Laval \\ Canada
}

Citation: Lambert, M., \& Bouchamma, Y. (2019). The development of competencies required for school principals in Quebec: Adequacy between competency standard and practice. Education Policy Analysis Archives, 27(116). https://doi.org/10.14507/epaa.27.4211 This article is part of a special issue, Standards and Competency Frameworks for School Administrators: Global, Comparative and Critical Perspectives, guest edited by Augusto Riveros and Wei Wei.

Abstract: School principals deal with a variety of increasingly complex responsibilities (Trudeau, 2013). They must therefore develop and hone professional competencies that will enable them to effectively perform their pedagogical, organizational, relational, or administrative duties (Barber, Whelan \& Clark., 2010; Bisaillon et al., 2009; Darling-Hammond, Meyerson, LaPointe, \& Orr, 2010; Pont, Nusche, \& Moorman, 2008). In light of the many societal changes and resulting pressure on schools, many countries have developed competency standards for school principals to redefine the competencies required to successfully fulfill this role (UNESCO, 2006). Quebec has followed suit in 
this movement with the publication of its first competency standard for school principals in 2008 . This document is used during the initial training for future school principals to develop competencies useful for this function. What competencies are needed by school leaders in relation to the challenges they face in their work? What are these challenges? Interviews with school principals $(N=13)$ allowed us to highlight challenges that arise in their day-to-day activities which allowed us to identify the professional and cross-curricular (behavioural) competencies that they implement to do their job.

Keywords: Competency Standard; Competency Framework; School Principals; School Leader Competencies

\section{Desarrollo de habilidades necesarias para directores de escuela en Quebec: Competencia y estándares de competencia coincidente}

Resumen: Los directores de escuelas se ocupan de una variedad de responsabilidades cada vez más complejas (Trudeau, 2013). Por lo tanto, deben desarrollar y mejorar las habilidades profesionales que les permitan realizar eficazmente sus tareas pedagógicas, organizativas, relacionales o administrativas (Barber, Whelan \& Clark., 2010; Bisaillon et al., 2009; Darling-Hammond, Meyerson, LaPointe \& Orr, 2010; Pont, Nusche \& Moorman, 2008). A la luz de los muchos cambios sociales y la presión resultante sobre las escuelas, muchos países han desarrollado estándares de competencia para que los directores escolares redefinan las competencias necesarias para cumplir con éxito este papel (UNESCO, 2006). Quebec siguió el ejemplo de este movimiento con la publicación de su primer estándar de competencia para directores de escuela en 2008. Este documento se utiliza durante la capacitación inicial para futuros directores de escuela para desarrollar habilidades útiles para este papel. ¿Qué habilidades necesitan los líderes escolares en relación con los desafíos que enfrentan en su trabajo? ¿Cuáles son estos desafíos? Las entrevistas con los directores de las escuelas $(N=13)$ nos permitieron resaltar los desafíos que surgen en sus actividades cotidianas, lo que nos permitió identificar las habilidades profesionales y transversales (conductuales) que implementan para realizar su trabajo. Palabras-clave: Estándares; competencias; liderazgo educativo; gestión educativa

\section{O desenvolvimento de competências necessárias para diretores de escolas em Quebec: Adequação entre padrão de competência e prática}

Resumo: Os diretores das escolas lidam com uma variedade de responsabilidades cada vez mais complexas (Trudeau, 2013). Portanto, devem desenvolver e aprimorar competências profissionais que lhes permitam desempenhar efetivamente suas tarefas pedagógicas, organizacionais, relacionais ou administrativas (Barber, Whelan \& Clark., 2010; Bisaillon et al., 2009; Darling-Hammond, Meyerson, LaPointe \& Orr, 2010; Pont, Nusche \& Moorman, 2008). À luz das muitas mudanças sociais e da pressão resultante sobre as escolas, muitos países desenvolveram padrões de competência para os diretores de escolas redefinirem as competências necessárias para cumprir com êxito esse papel (UNESCO, 2006). Quebec seguiu o exemplo desse movimento com a publicação de seu primeiro padrão de competência para diretores de escolas em 2008. Este documento é usado durante o treinamento inicial para futuros diretores de escolas para desenvolver competências úteis para essa função. Quais são as competências necessárias para os líderes das escolas em relação aos desafios que enfrentam em seu trabalho? Quais são esses desafios? Entrevistas com diretores de escolas $(N=13)$ nos permitiram destacar os desafios que surgem em suas atividades cotidianas, o que nos permitiu identificar as 
competências profissionais e transcurriculares (comportamentais) que eles implementam para realizar seu trabalho.

Palavras-chave: Padrão de Competência; Estrutura de Competências; Diretores de Escola; Competências de Líder de Escola

\section{Introduction}

\section{Redefining the Roles and Responsibilities of School Principals}

In an effort to improve the quality of teaching and academic achievement, it was necessary to redefine the roles and responsibilities of school principals in several areas (Corriveau, 2004; Mulford, 2003; Pont, Nusche, \& Moorman, 2008; United Nations Educational, Scientific and Cultural Organization (UNESCO), 2006). Two factors underlie the interest in the work of school principals:

1. Inspired by the Effective Schools Movement of the 1980s, many studies confirm that school principals influence the effectiveness of schools (Barber \& Mourshed, 2007; Davis, Darling-Hammond, LaPointe, \& Meyerson, 2005; Leithwood, Louis, Anderson, \& Wahlstrom, 2004; Leithwood, Day, Sammons, Harris, \& Hopkins, 2006; Louis, Leithwood, Wahlstrom, \& Anderson, 2010). These studies recognize that school principals contribute to the 'school effect' through their leadership, actions and influence.

2. In addition, interest in school principals has increased in the last twenty years, when several countries have revised their educational policies by implementing new educational reforms (Pont et al., 2008; UNESCO, 2006). These changes have largely changed the work environment of the school principals, where their workload has become more diversified (Corriveau, 2004; Gravelle, 2012).

\section{The Case of the New Educational Reform in Quebec}

Within this process of change seen in several countries, Quebec has also undertaken a reform of its educational system to provide a higher quality education. However, to make the implementation of these new orientations possible, major changes had to be made to the education act (LIP; Déry, 2004). For example, Bill 180 (1997), Restructuring of Powers and Responsibilities, provided greater autonomy for schools because each school inherited more responsibilities in educational services and in the management of human, material and financial resources (Dembélé et al., 2013; Pelletier, 2001). Management, a part of the administration (Barnabé \& Toussaint, 2002), is defined as "the administrative activity of taking responsibility for and caring for a sector of the organization or an activity of the organization" (Brassard, 1996, p. 17), in this case, a school. Then, a few years later, in 2002, the model of results-based management that focuses on the effectiveness and efficiency of schools was officially established in the educational community (Bill 124; Dembélé et al., 2013; Langlois, 2004; Maroy, 2013).

The decentralization of responsibilities and powers to the schools, combined with educational policy reform, have led to educational changes that require more of the school principals (Fullan, 2001); they must now work in an atmosphere where accountability and responsibility are required, while focusing on the students' academic achievement (Gravelle, 2012, Maroy, 2013). To reflect this new reality, efforts have been made to define the function of school principals in repositioning their roles and responsibilities while including the different facets of their work that necessarily have repercussions on students' academic achievement (Barber \& Mourshed, 2007; Pont 
et al., 2008). Also, in order to respond to the roles and responsibilities that have become more complex, school principals must develop specific and diversified competencies (Archambault, Garon, \& Harnois, 2014; Bisaillon et al., 2009; Dupuis, 2004; Guillemette, Morin, \& Simon, 2015; Ministry of Education of Quebec (MELS), 2006; Mulford, 2003; Perrenoud, 2002).

\section{Competency Standard for School Principals in Quebec}

Several countries consider the competency standard of school principals as a strategic tool to improve the quality of education (Pont, 2013). Conceived as a directory of good practices (Lenoir, 2010), the standard provides a common, reliable and shared information on which to base the development of competencies to be a school principal (Lecoeur, 2008). Le Boterf (2000), considers that a competency standard offers the possibility of developing individuals professionally because it encompasses objectives to be achieved in the context of a given professional situation.

In Quebec, the competency standard was created in 2008. This competency standard was designed to develop professional competencies by developing guidelines for the skills, knowledge and competencies required to fulfill the responsibilities of school principals (MELS, 2008). It guides the initial training in school management by providing guidelines for accomplishing the school principals' task because this document specifies the expectations associated with the function (Bernatchez, 2011; Gerbé, Raynauld, \& Téta Nokam, 2012; Paquay, 1994, Rey, 2006).

\section{Objective}

Ten years after the introduction of a guide for initial training in school management, it is appropriate to question the competencies the principals have put in place to face the challenges that arise in their day-to-day activities. Our objective is to identify the required competencies for school principals in relation to the challenges they face in their work.

\section{Conceptual Framework}

Three key concepts shape our conceptual framework: the notion of competence, the competency standard and the competencies that make up the competency standard.

\section{The Notion of Competence}

Competence represents implementing knowledge, know-how and attitudes, which are mobilized effectively in any given situation; thanks to the appropriate resources, the person will be able to handle the situation successfully (Jonnaert, 2005, 2009; Le Boterf, 2010). It is a "complex know-how that builds on an effective mobilization and a combination of a variety of internal and external resources within a range of situations" (translation from Tardif, 2006, p. 22). This implies that competence is in the doing, where internal resources such as knowledge, know-how and attitude, in addition to outside resources such as networks, peers, laws and procedures, will enable an individual to deal effectively with various situations in their work (Tardif, 2006).

Two types of competencies define the principal's roles and responsibilities (Pont, 2013). On the one hand, there are the professional competencies related to the tasks that are specific to the function of the school principal. These competencies are considered the "theoretical and practical knowledge a person has acquired in his professional field" (translation from Legendre, 2005, p. 257). On the other hand, there are the behavioural competencies related to attitudes and values that are useful in the context of the function. The professional and behavioural competencies expected for the function of school principals are identified in a competency standard that becomes a guide for 
the initial training of the future school principals to develop the competencies useful for them (UNESCO, 2006).

\section{The Competency Standard}

A competency standard (competency framework) is a tool that describes a number of competencies that will be useful in ensuring the roles and responsibilities of a function. It is considered as a reference (Paquay, 1994), a beacon that guides relevant professional practices to be built (Le Boterf, 2008), a directory of good practices (Lenoir, 2010) or a list specifying the competencies and aptitudes necessary to accomplish a task, exercise a function (Gerbé, Raynaud, \& Nokiam, 2012). "What the competency standard describes is strictly speaking only references. (...) These are targets against which individuals will enter into processes of building competencies will learn to act competently" (translation from Le Boterf, 2000, p. 5). According to the Australian Institute for Teaching and School Leadership (2015),

The standard gives expression to the leadership, educational and management requirements and practices of principals. The standard is an integrated model that recognizes all good leaders share common qualities and capabilities. (...) The standard provides a model against which principals can match their knowledge, qualities, experiences and skills to determine their strengths and areas for development (p. 10).

\section{Competencies (Professional and Cross-Curricular) within the Quebec Competency Standard}

The competencies that make up the competency standard for school principals in Quebec (MELS, 2008) will shape our conceptual framework (Figure 1). This competency standard is composed of professional competencies (10) divided into four management domains. Management refers to a "function that consists in ensuring the functioning of the whole organized in accordance with its constitution" (CERCLE, 1997, p. 22), like a school. In the Quebec school system, management refers to the educational services of the educational institution; the educational environment of the educational institution; the human resources of the educational institution and its administration which are defined as follows:

1. The Management of Educational Services consists of two professional competencies:

- Build a school organization centered on the educational needs of students; - Support the development of educational practices adapted to the needs of students ${ }^{1}$.

This implies that the school organization must focus on the needs of the students and the teaching practices must be adjusted accordingly.

2. The Management of the Educational Environment includes three professional competencies:

- Assist the governing board in exercising its role as stated in the law;

- Lead the development of an educational program and the implementation of a plan geared to the students' academic achievement; - Support the development of collaborative and student-driven partnerships ${ }^{1}$. This implies that decision-making must be done as a function of the school's situation. This means the analysis must be based on achieving the objectives set by the community. 
3. Human Resources Management consists of three professional competencies:

- Ensure competent action in one's own practice and in that of each staff member;

- Ensure competent action in each team at the school;

- Ensure the development of their competencies and those of all the staff members ${ }^{1}$.

This implies that the definition of the roles and responsibilities of each staff member must be pursued in order to improve practices, while working together for students' academic achievement.

4. Administrative Management consists of two professional competencies:

- Effectively and efficiently manage financial resources;

- Effectively and efficiently manage material resources ${ }^{1}$.

This implies that the financial and material resources must contribute to achieving the educational mission project of each school.

In addition, there are six cross-curricular competencies (transversal competencies) that encompass the professional competencies associated with the four management domains and make the difference in this competency standard (MELS, 2008). Cross-curricular competencies are defined as an "intellectual, methodological, personal, social or communication know-how that goes beyond the boundaries of disciplinary knowledge, while deploying it and promoting its acquisition and their reinvestment in real situation" (translation from Brahimi, 2011, p. 32). According to the MELS (2008):

cross-curricular competencies permeate all the competencies required to manage an institution and are embedded in all the professional situations school principals face. To this end, these are the competencies which are the basis to structure and develop the competencies to appropriately manage schools (translation from MELS, 2008, p. 30).

These six cross-curricular competencies are:

1. Method / Approach (allows the transfer of formalized and experiential knowledge);

2. Communication (ensures a common language leading to a shared vision);

3. Leadership / Political Sense (encourages everyone to be involved in a joint project);

4. Interaction / Cooperation (establish favorable conditions for exchanges leading to fruitful collaboration);

5. Evaluation / Regulation (reflection on the process of professionalization of the administration through its practice, follow-up of the results);

6. Ethics (balancing student values and the interests of the school).

In short, the professional competencies associated with the four management domains and the cross-curricular competencies form a whole, where knowledge, know-how and attitudes allow school principals to be well equipped to exercise their roles and responsibilities to ensure students' academic achievement. Figure 1 resume the relation between management domains and crosscurricular competencies of the Quebec competency standard (MELS, 2008) shown in Appendix 1.

\footnotetext{
${ }^{1}$ from MELS, 2008, p. 32 in Appendix 1.
} 


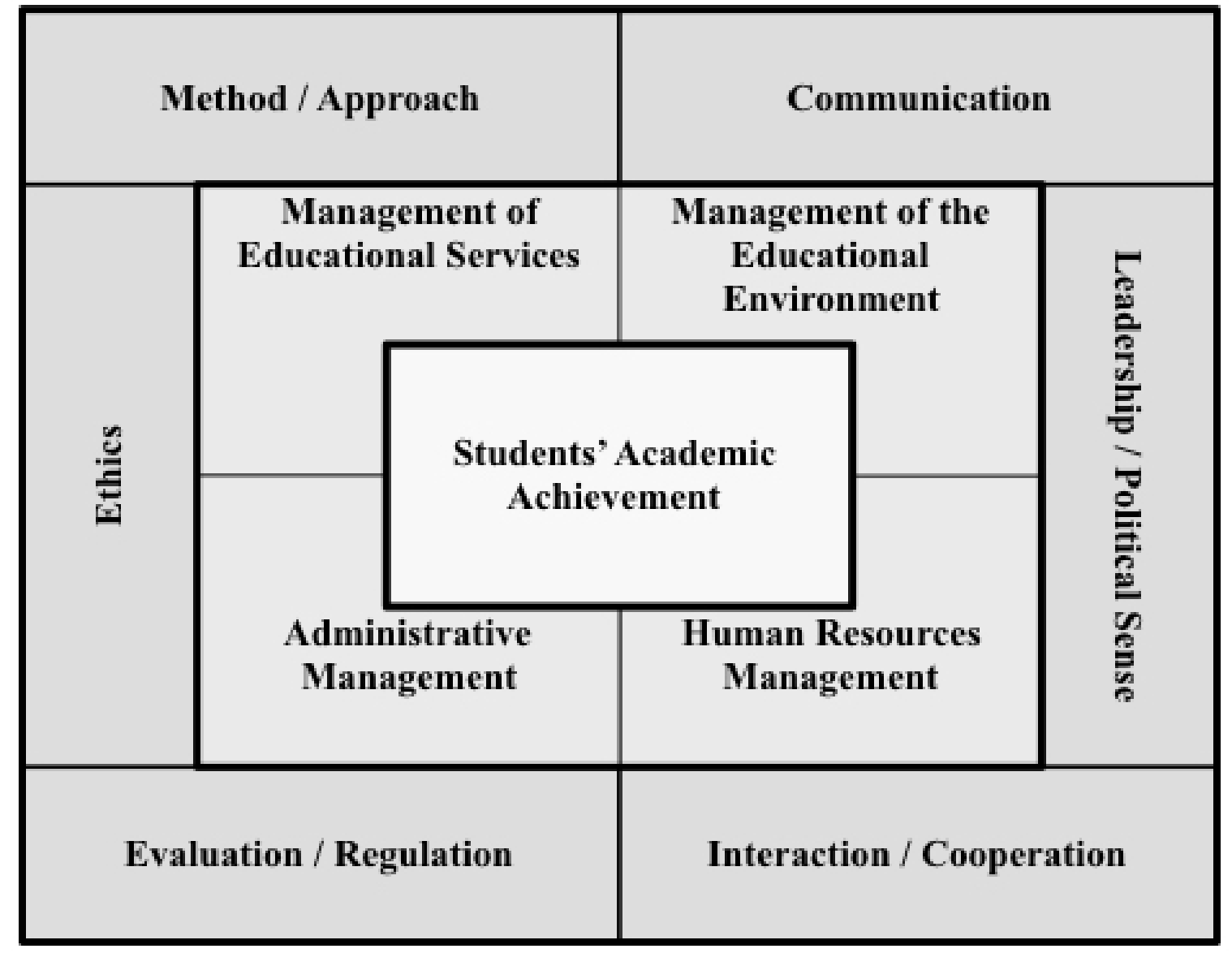

Figure 1. Management domains (4) and cross-curricular competencies (6) required for the school principals' work

\section{Methodology}

\section{Participants}

The participants are school leaders $(N=13)$, eight of whom are principals and five are viceprincipals that are part of a research project about professional development conducted by one of the authors in which they participate on a voluntary basis. The objective of this project was to form a virtual community of practice over a two-year period during which school principals would discuss about their challenges and thus help each other in their professional development. The person in charge of this project contacted the Association Québécoise du Personnel de Direction des Écoles (AQPDE), asking them to share with their members the possibility to participate in this project. Depending on the availability of the dates chosen and the interest in sharing about their practice with others colleagues, 13 participants registered to be part of the project. Among them, 11 are women and 2 men, who come from school boards or private educational institutions from different regions of Quebec. Nine work in primary schools, four work in high schools. The work experience of these participants ranges from a few months to 10 years as school principal. 


\section{Data Collection and Analysis}

Semi-structured interviews were conducted with school principals and vice-principals to determine the challenges they face in managing day-to-day activities in their school and the means they are implementing to meet these challenges. We gave two questions to each of the participants before the interview, so that they could begin their reflection:

1. Tell us about the challenges you face in your day-to-day school life?

2. What means did you use to meet the challenges in your work? What was useful to you in achieving your objective? Explain.

Then, during the interviews, lasting from half an hour to one hour, we were able to deepen the answers with sub-questions. All interviews were conducted by the same person who was authorized to record them.

Once the data was collected and the interviews transcribed, we analyzed the data according to the principles of Miles \& Huberman $(1984,1991,1994)$ using a three-step analysis process consisting of:

1. Condensing the data (classification, reduction, coding);

2. Presenting the data; and

3. Formulating and verifying the conclusions.

The qualitative data analysis software QDA Miner was chosen to process the data. The use of QDA Miner allowed us to extract portions of interviews by grouping them into categories according to a coding list. The mixed coding, that means the initial list may be modified, complemented or reduced during the analysis, has been retained (Van der Maren, 2004). The coding list is based on our conceptual framework related on the professional competencies associated with the four management domains as well as the six cross-curricular competencies of the Quebec competency standard (Figure 1). From the data collected, we were able to associate the majority of the themes with our coding list based on the Quebec competency standard, but we also had to add new themes to it, based on the data collected from our participants (emerging themes).

Finally, to ensure the reliability of our results, the first coding was done twice by the researcher. Then, a second coder did the same exercise independently. Subsequently, the two coders compared their list to reach a consensus.

\section{Results}

In this part, we present the results provided by the interviews of the school principals and vice-principals. At this way, interviews were conducted to assess the daily challenges addressed by school principals in regard to 1) professional competencies in the different domains of management (MELS, 2008) and 2) the cross-curricular competencies required that the school principals (MELS, 2008) must possess to fulfill their role.

\section{Part 1: Professional Competencies Required to Face up to Challenges of School Principals}

In this first part, we will present professional competencies according to the four domains of school management named in the Quebec competency standard that are associated to the challenges that face up school principals in their tasks (Table 1). 
Table 1

Professional competencies related to the domains of management (MELS, 2008) needful to the challenges that take on school principals in acquiring their tasks $(N=13)$

$\begin{array}{cll}\text { Professional Competencies } & \begin{array}{l}\text { Current challenges } \\ \text { of school principals }\end{array} & \begin{array}{l}\text { Data collected } \\ \text { from participants } \\ (N=13)\end{array} \\ & & \end{array}$

\section{Management of Educational Services}

1. Build a school organization centered on the Management of

2. Support the development of educational Developing the practices adapted to the needs of students. educational project

\section{Management of Educational Environment}
4. Lead the development of an educational
Adaptation to change 10
program and the implementation of a plan
geared to the students' academic
achievement

\section{Human Resources Management}

6. Ensure competent action in one's own practice and in that of each staff member
Balance between a

5

personal and a

professional life

7. Ensure competent action in each team at the Managing of staff 5 school

8. Ensure the development of their competencies and those of all the staff members
Importance of the 4 network

\section{Others}

Management the unexpected

Stress management
3 


\section{Domain 1 - Managing Educational Services: Professional Competencies Related to Challenges of School Principals}

Educational project. According to 8 out of 13 participants, the educational project is very useful as a central point to rally teachers and other school stakeholders in collaborating for the school's first mission: successful schooling of students. Many see the educational project as a rallying element in their school: "The educational project, we do it as a team, we decide together on how we will go about it, on how we will put it, it's there were people feel involved since it is not imposed" (DIR13). This school principal uses questioning methods to involve is staff members in the educational project: "How will we be able to get through our school's educational project? Everybody is part of the solution" (DIR13).

The main challenge associated the educational project is to be able to propose it as being in service to the schooling practices: "I think that by having dynamic educational project, it makes all the difference. We really don't want to create a document that will be shelved and revised each year" (DIR 01). The educational project creates occasions for school members (stakeholders) to collaborate. Moreover, this collaboration helped establish, in certain occasions, learning communities: "I used the educational project to develop workshops that I now call Learning Communities (LC)" (DIR04).

Management of priorities. Five out of 13 participants feel that priority management is a very important challenge for school principals, especially for those in that are at the beginning of their careers: "Managing priorities, it's something that was hard for me in the first years. It's however a key skill to have in the beginning of your career to know which problems to address first, otherwise, we could work 150 hours weekly" (DIR08).

To manage priorities, some people evoke the ability to rank their workload according to its emergency or importance, and the necessity to be organized: "Time management, knowing how to prioritize adequately and realize important tasks so that we're not last minute, to have a good view, a good sense of organization, and to maintain an adequately organized agenda" (DIRADJ03).

Nevertheless, tasks are added to the planned workload:

In regards of the workload, the main challenge, it's really about managing priorities. Therefore, time as to be taken to analyze each file that's added to the pile on my desk, that appears without warning. We need to analyze how we will manage it along with every task already set on the timetable. So we have a timetable for the tasks at hand, but there are always unexpected setbacks, so we need to add everything on the timetable and achieve accordingly to standards (DIRADJ02).

Managing priorities in school for the academic achievement of students sometimes conflict with school board's priorities: "There is a time where different demands for services by the school board are brought up, we are asked to deliver for a certain date, and that is without regards of daily tasks in school, so it becomes the main challenge to focus on school's daily management tasks and the legally binding student follow up" (DIR05). The same school principal added: "We are always caught between our emergencies and the timetable where we have to fill the forms, for example, or others demands. However, our needs are most important" (DIR05).

\section{Domain 2 - Educational Environment Management: Professional Competencies Related to Challenges of School Principals}


Adaptation to change. Ten out of 13 school principals consider that adaptation to change is the main challenge to which they are confronted too on a daily basis. Remediating about this issue, school principals have to assess which actions they must prioritize. School principals stress on the necessity to adapt to the numerous situations that occur daily: "We are very solicitated on our ability to adapt on a daily basis" (DIR05). Incidents that occur daily must be prioritized, which brings changes to the agenda: "We must accept to put off tasks for a moment. Tasks we had planned on the timetable and now prioritize new elements broth forth by unexpected events" (DIR04). A mindset that is shared by another participant who explains: "We must adapt and prioritize on a day to day basis. We have no choice. I must be able to turn around. We put aside certain tasks and preform them latter" (DIRADJ12).

School principals stress the fact that they have more and more tasks to do enabling them to make quick decisions without taking a certain distance: "We don't have the time to take a step back to make our decisions" (DIR09), "I'm too busy to make decisions and I find that hard" (DIRADJ11). On the other hand, precipitated decisions can meet resistance:

The number of files keeps increasing. My colleagues are also under the impression that files are piling up and that time goes by so fast, which brings us to quickly modify our workload, whether you want it or not, you will be confronted by the reluctance of colleagues (teammates). We must work harder with colleagues (DIR09).

\section{Domain 3 - Management of Human Resources: Professional Competencies Related to Challenges of School Principals}

Balance between personal or professional life. The ability to find balance between professional and personal life was evoked by five participants out of 13 . They talked about a necessary balance between family time and work. This issue must be considered upon hiring, otherwise medical concerns appear:

I have kids and this equilibrium, it's something. We must be watchful, even while recruiting school principals. Those are the main issues involved. It's really hard when you have a family. You must know when to let go. There will always be emergencies. We must be careful and not get sick with that (DIR09).

The multiple daily tasks aren't always acquitted at the end of the day which compels many to continue their work at home:

We must have the ability to react quickly. The "to-do-list, you aren't always alone in your office with the door closed. There are always people getting in my office for a minute or two. At the end of the day, I've only been able to perform one or two items on my list. Either I bring it home or put it off until tomorrow (DIR08).

This situation leads to a work surcharge which brings its load of stress upon school principals. One school principal mentioned:

In managing so much stress and pressure, including all the appropriation, the amount of time spent to address these issues is incredible. For a given moment, you become out of balance and you don't want to go back out of balance (DIR05).

Abiding in the same direction, others keep in mind self-management and remain vigilant thus avoiding a work surcharge and keeping an equilibrium in their life: 
I would say that, on a personal basis, energy management, it's something really important necessitating attention because it is easy to lose sight of goals with long work hours. So, firstly, I would say that self-management is a key element in being a good manager of one's energy (DIRADJ03).

Managing staff. Five out of 13 participants stated that there are some situations where they have to compose with staff members having different personalities and for which school principals did not participate in their hiring: "We must compose with diversity. It's not a choice, and it is imposed upon us" (DIR05). Furthermore, school principals stress out unpredictability, sometimes having unexpected behavior, even contradictory: "We live with humans and their unpredictability and contradictions. It's not always easy" (DIR04).

The main challenge is to manage, in the same workplace, a diversity of personalities so that they fully engage in teamwork without transgressing their role: "The biggest challenge, is team cohesion, keeping in sight the framework, the roles and functions of each teammate. That is my challenge" (DIRADJ12). This situation is the root of conflicts: "Everybody as to be at their place and not at someone else's" (DIRADJ12).

Some of the school principals related situations where some of the personnel knew how to address their demands: "They (members of the staff) learn how to know us and they know what to ask of us and what they can't ask. They learned our ways of dealing with demands. They know how to manipulate when they know us" (DIR04). The hierarchy that is set forth by school principals and the staff is sometimes a source of misunderstanding: "small conflicts, everyone's caprices, managing employees is always a big challenge so that everybody gets along. There are always little things. We work with humans" (DIR07). Others say it's a good thing to focus on the team's good shots: "We have to recognize the good work of the personnel (teaching body). We have to congratulate and encourage them" (DIR07).

Attendance is a preoccupation:

We lack personnel. Thus, we must be very creative and crafty to substitute teachers since we have no one to fill in the gaps. I can get to work on a Friday morning and the secretary will let me know that there are two teachers who are absent. We can't find substitutes, so I go and do gymnastics (DIR07).

The fact is, to find substitutes is a time and energy consuming task: "The lack of personnel, their retention, it actually takes a lot of time to substitute personnel” (DIR09).

Importance of the network. Some participants reported the utterly importance of having a network. Four out of 13 said that it gives them a stronghold on things. They recognize the importance of being able to rely and exchange with peers to break the solitude and for their professional development, and this, especially in the beginning of their careers.

The passage from being a teacher to being a school principal is often done in exclusion of the initial network (teachers body). Thus, solitude sets in for the new school principals:

There is the network that is very important since it is a major difficulty when it happens, the isolation (loneliness) when we pass (from a stature to another). Here, I'm really talking about insertion in the workplace for a new school principal. But to pass from a mindset of collegiality where when you're a teacher to being an outcast when you're a school principal, that is a major change in perspective (DIRADJ03).

Keeping contact with other colleagues who are school principals helps to relativize decisions: 
And yes, we have to take the time to call sometimes. To appraise. Do you think that, since it adds a new view on the matter, certain files? This new point of view is essential. It's a lot like when we ask our teachers: go see in the other classroom what's going on. I don't think it's good to be proud and say no. In my school, I won't decide alone. We have to get different point of views from colleagues (DIRADJ03).

The network can give you some answers: "If I have a question, my answer, I will get it from my network because there is someone who knows the answer" (DIR06). In those networks, younger school principals benefit from their elder's experience: "Between us, we must nourish ourselves. We need to know what's going on with other colleagues. We need to talk to each other. The elders will give us their comments. The network is essential" (DIR06).

They exchange material like documents "I have a really nice network. I would say that we are 7-8 school principals who work very well together. We try to share what we find, what we discover, good books, references and all" (DIR07). And for some occasions, the network can facilitate the sharing of information to find human resources: "We were lacking personnel. We asked people in our network where we could find people" (DIR09).

\section{Other Professional Competencies Related to the Current Challenges of School Principals}

Managing the unexpected. Undeniably, unforeseen or unexpected situations happen in the daily workload of school principals. This school principal relates: "As a matter fact, what is the most challenging, is the unexpected or the unforeseen. That's what it says. We can't manage it. It just happens and then we deal with it. It's more like that" (DIRADJ02). Added to that, like this participant underlines, it's the personnel's attendance that is a big part of unforeseen events that we have to manage: "We don't know in the begging of the day how it's going to go. Whether it's the substituting, the attendance, the crises, since I manage a school who has fragilized students" (DIR04).

Unexpected situations present themselves in different ways as this school principal testifies by giving different examples:

Unexpected events come from different sources. It can be a parent who needs to rant for $x-y-z$ reasons. It can be the school's janitor. It can be someone who created an oil spill and we have to establish a secure boundary. It can be workers that drop in my office when they weren't expected. Everything is possible (DIR05).

Again, like this other participant testifies, we must make time for the main files so that things keep getting done. Often, that time is made at the end of the day:

After the students have gone home, it the equivalent of one day's workload because there isn't anyone around. It's then that we do the administrative part of the job. We do the paperwork. Before, we extinguish fires. We deal with problems. We can't do everything that needs to be done (DIR06).

Stress Management. Different daily situations bring their load of stress for the school's principal. One participant relates the beginning of a day's work:

You have to make sure that the school is functioning. So, even if you wanted to work on our super educational project, because this takes a lot of time, but if there are some school personnel missing, me, I have to ensure that the students are getting the adequate services because that's the priority with my job (DIR05). 
This school vice-principal relates the same fact and adds that the rhythm of the workload can have repercussions in the personal life:

This brings me to another topic which is stress management because, sometimes, it happens that we have three, four events at the same time. We have short delays with which we have to compose and eh, someone who, about self-management, has problems managing stress, well, it can possibly be a very important challenge for him of for her and it is going to spill in their personal life (DIRADJ03).

These situations demand a lot of maturity on the school's principal behalf so that he or she can be in a solution mode with his or her teammates and to assume each given responsibility. This participant explains:

If you're not able to have it (maturity), you will have problems with stress management. Balance is a thing, but pressure is another. It's as if you were always stuck between a tree and its bark. The ministry has its demands and it is up to the school board to be sure that their schools meet those demands. This brings timetables. For us, on our behalves, if we bring forth our prerogatives to our team, it can decide to sabotage everything and not collaborate. So we must absolutely find meaning in our work environment (DIR05).

\section{Part 2: Necessary Cross-Curricular Competencies (Transversal Competencies) Required to Face up to Challenges of School Principals}

In this second part, necessary cross-curricular competencies to overcome challenges will be underlined by school principals' and vice-principals' testimonies. (Table 2).

Table 2

Necessary cross-curricular competencies needed by school principals in their practice $(N=13)$

Cross Curricular Competencies (MELS, 2008) Most Required From the Day-to-Day Activities of School Principals

Collaboration

Leadership / Political Sense

Communication

Listening

Other Cross Curricular Competencies

Emotional intelligence

Previous teaching experience
Data collected from participants $(N=13)$

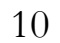

9

6

6 
Collaboration. Ten out of 13 principals and vice-principals expressed the utterly importance of collaboration in the daily execution of tasks. Many school principals have underlined the importance to have good teammates that are collaborative: "The biggest asset of my school, it's the mobilization of my teammates" (DIR05). "I have a great team that participates well" (DIR13), and furthermore "We are many to have our school "tattooed" on our hearts. That helps a lot on a daily basis" (DIR08).

School principals explain that employees who collaborate helps them in the shift of practices since: "It gives leverage to shift practices when we are united" (DIR07) because "one teacher says to others -I will bring my computer and show you how it works. This favorizes collaboration with each other" (DIR04). Another principal adds: "What's nice is the influence that peers have on each other; you just need one that will collaborate with you, and the others will say ok, ok. I think that peer influence, it is very, very important" (DIR07).

On the other hand, other school principals explain that they must be sure that the personnel will collaborate. They must to be willing to do it voluntarily. Consequently, you have to find projects that are in their interest. These things are done gradually: "It adds to nothing to impose, you know. When you impose things, people immediately are refractory, but if we begin with voluntaries, it's with them that we have to work with. This influences others" (DIR04), this is corroborated by another principal who affirms encouragements are incentives for others to begin collaborating:

I have certain elements who must be mobilized a little more. But with these people, it's small steps at a time. Sometimes, you must present your project, an idea, a mandate and we don't know, they do a little bit more than usual (DIR13).

This other participant adds that the influence of some of the personnel on others helps to have a better collaboration: "What's nice is the influence that peers have on others; You just need few that are on your side and are willing, then the others say ok. I think that peer influence, it is very, very important" (DIR07). A statement that is also shared by another school principal who explains that: "If you're 5 to believe in the project, it would be nice to be 25 to believe in it, next time" (DIR08).

However, for this reason school principals must be on the lookout of what is going on in their school so that they can keep their team mobilized. This participant relates:

Even me, in my principal's chair, I have to go in the classrooms. I have to walk in my school because otherwise, I only have the administrative perspective of my school, and that is sometimes the issue with my teaching body demobilization (DIR05).

The school's educational project is a good incentive to get the teaching body to collaborate. This principal shared:

We work to elaborate our educational project and the major change, well, it's that we don't want it to be out of context and done in some office with the door closed. We encourage the teachers and other personnel to share their point of views to eventually endorse the educational project so that it is viable for the next five years (DIRADJ03).

This vice-principal explains that, sometimes, it's time taking to involve personnel in the decisionmaking process. But there are many advantages to do so: 
All the decisions that we make, it takes twice as much time that if we did it alone in our office. So, we make those decisions together, so they feel involved. They have a voice and once they've decided together, since the majority has spoken, everybody goes in the same sense. If some don't follow, they're excluding themselves from the decision-making process (DIRADJ10).

Leadership / Political Sense. Nine out of 13 noted that their leadership is a very useful cross-curricular competency to have. Consequently, one principal relates that without leadership, the job can't be done:

I can't think that someone would want the job if they didn't have any leadership. I think that would be problematic. It's one of the fundamentals of being a school principal to be able to gather and be solid. It is an essential skill to have (DIR05).

This other participant underlined that, sometimes, this situation demands an introspection on the behalf of the school's principal: "You have to ask yourself why the teachers think you don't have what it takes. Maybe they're questioning your leadership" (DIR01).

About leadership, one school principal adds that: "I know where I'm going and I say it out loud; we're going there. We won't be taking any detours, it's there that we're going” (DIR06), while another participant underlines that leadership is a priority in preforming your duties: "We know it's the first element, leadership. We know too well of its importance to mobilize the team, to bring on a shift in practice" (DIR07). This other principal explains that his leadership helped realize some projects: "Leadership... they saw that I'm someone who's able to take on a project and realize it, that I'm someone who's solid and experienced. I brought my ideas to the table and they saw" (DIR06).

This posture was equally pointed out by another school principal who saw in his leadership a way to get things done:

Being a good leader, it's important for the principal, honestly. I think that being in my office and administrating the school is one thing, but to be on the terrain and making things progress and bringing about a shift in practices, it's a daily challenge. I think it's part of being a principal (DIR07).

One participant mentioned that it can be useful to be strategic and to develop good management policies in your work so that you have other people's support in the decision-making process: "All this sort of network of influence to bring about change, it calls for a lot of strategies and of course, opportunity" (DIR05).

Communication. Communication is underlined by six out of 13 participants as being the cross-curricular competency of utter importance. This competency helps personnel to better understand the principal's decisions. This participant explains: "We have to explain if we want to rally people" (DIR13). Furthermore, this vice-principal mentioned that communication allows all the school's body to receive the same message: "We have to sit everybody around the table so that everybody ears the same message and the same message is being broadcasted" (DIRADJ12). On the other hand, another school principal relates that verbal communication is better for sharing information than e-mails. This school principal sets informal meetings to establish a relationship with his personnel: "In the corridors, we talk. It's better than e-mails. The contact is different" (DIR06).

When there is a shift in policies or practices, this school principal explains that communication is a key element for the stakeholders' understanding the fundamentals of change: 
To be able to bring upon change, we must communicate. People must feel like they're partaking in this change. Therefore, they have to be informed of the changes being set forth and where the direction the policy shift is taking them (DIR04).

This other participant explains the incentives that good communication can have while proposing new projects whom are favorable to the school: "We have to talk to each other. They (teachers) know that they can propose new projects" (DIR07). Furthermore, communication can uphold positive reinforcement. This school principal takes time to highlight his team's good "shots" while in meetings: "We talk about the good shots together while in general assembly and people feel valorized and empowered" (DIR13).

Listening. Good listening has been stressed by six out of 13 participants as being fundamental for the school principal. One participant explains that being listened to enables him to make changes in his work environment: "We must lend an open ear to be able to adapt to change" (DIR04) while this other school principal upholds that listening helps for counseling with employees: "I listen to you and try to find opportunities to help you" (DIR05). Another school principal relates that listening rallies his teammates because: "People mobilize because the feel listened too" (DIR13), which a third party equally mentions: "We must lend a very open ear, that what I learned in these past years. It leads to nowhere when you want to go to fast" (DIR04).

\section{Other Cross-Curricular Competencies Related to Current Challenges Listed by School Principals}

Emotional intelligence. Being able to express empathy has been pointed out as a valuable asset by three out of 13 participants. One school principal explains that emotional intelligence helps him to better understand others: "We work with humans, it's (emotional intelligence) a basic competency: working with humans and being attentive to their needs, it's a wining situation" (DIR13). Another vice-principal relates that emotional intelligence remains an asset that allows him to keep track of his team and to check if its needs are adequately addressed:

Being reunited around a table to discuss about practices is one thing, but it's another to alter your own practices for teachers. It's a little bit hard. So, it's a lot to ask. I would say that emotional intelligence helps you to foresee things that are too hard to ask to the teachers. Sometimes teachers need to be better equipped to carry out demands. So, it's better to be a principal that listens to his teachers (DIRADJ02).

Previous teaching experience. Two out of 13 participants mentioned that the teaching experience they acquired before becoming school principals was very useful for understanding teachers, that this helps to have interesting conversations with the teachers body. In fact, this principal explains that his experience reassures his personnel who feels a lot more listened to when exchanging on practice: "You know what it's like being a teacher. It's a winning situation" (DIR07), which is also upheld by another participant:

Having been 19 years as a teacher in three different schools really helped me when I started has a principal. Having experience, I was a lot more coherent, what I said maid sense, my experience served me well. Experience in teaching is a big plus (DIR06).

\section{Discussion}

After interviewing school principals about the key challenges that arise in their day-to-day activities, we were able to identify the professional and cross-curricular (behavioural) competencies 
that they implement to do their job. The analysis of the means that the school principals use to meet the day-to-day challenges refers to:

1. Professional competencies required in managing educational services, the educational environment and human resources where the challenges lie in adapting to change, developing the educational project, maintaining a balance between a personal and professional life as well as the management of staff and priorities. These elements are mentioned in the competency standard as being required for the school leader, but the management of contingencies and stress cannot be linked to competencies identified in the Quebec competency standard (MELS, 2008).

2. Cross-curricular competencies related to collaboration, leadership / political savvy and communication / listening. We consider that listening is linked to communication because one does not go without the other; being attentive to what message communication gives us is an excellent indicator of the state of health of a relationship because listening is as much a part of communication as speaking (Parson, 2000; Weisinger, 2005). However, emotional intelligence and previous teaching experience are emerging themes that were not included in our coding list from the Quebec competency standard (MELS, 2008).

Thus, school principals highlighted some professional and cross-curricular competencies useful in doing their work and meeting the challenges they face. According to the data collected, it seems that the competency standard remains a tool that ties in well with the day-to-day practice of school principals and competencies needed for the function. Although it dates back 10 years, the crosscurricular competencies as well as the professional competencies described in the management domains generally reflect the practices of school principals useful to the challenges they have to go with.

\section{Cross-Curricular Competencies and Professional Competencies Most Required in the Day- to-Day Activities and Challenges of School Principals}

Collaboration and leadership / political savvy remain the two cross-curricular competencies most often named by school principals as being necessary in the context of their work. These results confirm that school principals must, through various measures, encourage teachers to work collaboratively so that, together, they can find solutions to the different needs of students (Corriveau, Boyer, \& Fernandez, 2009). Inevitably, school leadership becomes an asset to achieve this. The educational project, for example, remains an excellent way to share the different expertise within the school, in a spirit of collaboration where the leadership of the principal will also be harnessed.

Collaboration appears to be a factor for students' academic achievement (Lessard, Kamanzi, \& Larochelle, 2009) that seems to be well integrated in schools today, according to the results obtained. School environments are increasingly working towards a collaborative culture that requires the participation of teachers in decision-making; this was not done prior to the new education reform of the early 2000s (Gravelle, 2012).

Whereas formerly teachers worked separately in their own classroom, collaboration is now becoming prevalent; within the school environment, Learning Communities (LC) are a great opportunity to share and engage in a constructive exchange to put students' academic achievement as a priority (Dufour \& Eaker, 2004; Leclerc, 2012). This collaboration allows the different team members to improve together as everyone shares their expertise and experience; this greatly facilitates the changes to be made in the school environment (Fullan, 2010). In this respect, the sharing between the various members of a school-team seems well recognized by the school 
principals interviewed who understand the importance of putting the focus, through different means and projects, on the collaboration practices of the team.

The principal's leadership contributes to strengthening the collaborative culture within the school team. Through their behaviors and practices, school principals inevitably influence their staff (Legendre, 2005). Amongst the principals interviewed, leadership does not seem to be a competency that is questioned regarding its benefits, they consider it to be quite natural, since having leadership is the hallmark of a good school principal (Legendre, 2005).

By virtue of their function, the school principals must be able to mobilize their team (Fullan, 2012) and to achieve this, they must demonstrate, among other things, leadership. The effectiveness of a principal's leadership contributes to improving students' academic achievement (Leithwood et al., 2004; Leithwood, 2012) because it validates the team so that it then works to achieve success. Thus, through its practices and actions, school principals act as a lever to improve school effectiveness by directly influencing the work environment, the motivation, the attitudes and the behavior of teachers, thereby indirectly contributing to the improvement of students' academic achievement (Lapointe \& Gauthier, 2005; Louis et al., 2010; Pont et al., 20008; Scheerens, 2016; UNESCO, 2006).

\section{Emerging Themes}

Four themes were added to our initial coding list (Figure 1) which, it should be remembered, came from the Quebec competency standard (2008) (Appendix 1). These are emotional intelligence, previous teaching experience, stress management, and contingency management.

Emotional intelligence. The school principals mentioned emotional intelligence as a useful competency in meeting the challenges associated with their work. Since emotional intelligence makes it possible to understand both one's own emotions and those of others (Goleman, 1997), it is a competency that can facilitate communication (Weisinger, 2005). Moreover, according to Weisinger (2005), sensitivity arises from emotional intelligence, and illuminates the effects of communication on feelings, thoughts and behaviors, in order to adjust the way of communicating accordingly. Considering that school principals occupy a function where they will have many opportunities to manage their emotions, it is an interesting competency to focus on with school leadership.

Also, according to Goleman (1997), 80\% of leading success is composed of the appropriate use of emotional intelligence; it goes without saying that this is a competency that must be encouraged to develop if we want to have effective school principals. For example, when handling files, the school principals must understand their impact on other people and take into account the effects on them (Gravelle, 2012); in this respect, emotional intelligence can become an asset since it consists in using one's emotions intelligently so as to guide towards appropriate behaviors and thought (Weisinger, 2005). All in all, emotional intelligence can provide benefits to school principals which will in turn affect their interpersonal relationships in their work.

Previous teaching experience. Before holding a position of school principal in Quebec, you must be utterly qualified and experimented. Usually, it is recommended to have at least five years of experience as a teacher before shifting to a school principal (Bernatchez, 2011). This experience in teaching is compulsory for it helps school principals to better understand what schooling all is about. Even more, experience helps school principals and vice-principals set their minds on what is the job and if they have an interest for it (Bernatchez, 2011). Also, stakeholders relieve school principals are often recruited right in of the teaching body, where some teachers show much leadership. Thus, we are not so surprised by the fact that teaching experience has been excluded from the Quebec competency standard (MELS, 2008) because, by definition, school principals must be recruited from the teaching body. In fact, school principals are teachers with an 
overview of schooling and administrative responsibilities. Those are minimum requirements so that the role and responsibilities of school principals are properly performed.

Stress management. Our participants acknowledge using stress management strategies daily and yet, this competency is absent from the Quebec competency standard (MELS, 2008). Holding office as a school principal has tremendously changed through the years in regards of the assignment and the conditions of exercise as well. For example, the reform of the entire educational program and accountability are contributing factors of the degree of difficulty of the task (Brassard, 2009; Ingvarson, Anderson, Gronn, \& Jackson, 2006; Mulford, 2003; Pont et al., 2008; UNESCO, 2006). Therefore, the multiple requirements for the task and ever-increasing public expectations should uphold stress management as unavoidable competency for holding office (Mulford, 2003; Poirel \& Yvon, 2011; Poirel, Yvon, Lapointe, \& Denecker, 2017).

Working conditions and administrative constraints are continuous sources of stress for the school principals. They start early in the morning and work late. They sometimes bring work at home. Even more, going from vice-principal to principal is a big step to take and it comes with its load of stress (Fédération québécoise des directions d'établissement d'enseignement (FQDE), 2009; Poirel et al., 2017). Even though initial training is compulsory, the lack in personnel and qualified candidates might lead to hiring an uncertified teacher for the office (Armstrong, 2009; Poirel et al., 2017). This situation adds once more to the load of stress for school principals. Because of these numerous reasons, stress management must be part of a sensitization program for school principals since their responsibilities never cease to increase (Fortin, 2006; Mulford, 2003).

Managing the unexpected. Managing the unexpected events has also been underlined by most participants as part of the task. Fact is that a great part of the daily workload for school's principals is managing the unexpected and the unforeseen. These events that school principals must face up come from a variety of sources, whether there provided from administrative aspects of the task or from conflictual human relations of the regular staff or outsiders. Also, predicting the unforeseen isn't the solution, which brings the school's principal to compose with it by proceeding urgently and making decisions with a degree of uncertainty (Perrenoud, 1996).

Consequently, adapting to the unexpected situations is inevitable. It seems to us that initial training for school principals should focus on the impact that personal efficiency has on school's principal's professional development and should follow thru all along their career with this particular aspect. Thus, if school principals were better sensitized to Bandura's $(1977,1986,2003)$ theory on self-efficacy, they would be empowered and rely on their full potential as they develop competencies to face up to unforeseen events that show up along their careers.

\section{Cross-Curricular and Professional Competencies in Domains of Management Whom Have Not Been Addressed by School Principals}

Ethics is the only cross-curricular competency include in the Quebec competency standard (MELS, 2008) that was not stated in the interviews by school principals and vice-principals. However, we can recognize in their discourse one of the three forms of ethics according to Langlois (2012), that is to say solicitude through emotional intelligence which was noted a few times in the interviews.

Also, professional competencies associated to the domain of administrative management were not addressed directly by participants in the interviews. This would be explained by the fact that the interviews were conducted while school resources were not scarce due to budget cuts. 


\section{Conclusion}

This qualitative study aimed to identify the competencies required for school principals in relation to the challenges they face in their daily lives. We have seen that the functions of school principals have become more complex. This is why school principals need competencies to address the multiple challenges they face in their work. In Quebec, universities responsible for initial training to become school principals use the competency standard (MELS, 2008), available since 2008, thus helping school principals to acquire the competencies expected for this function.

The results of our research show that the competency standard effectively guides school principals to face challenges in their daily lives through the competencies they have developed. We were able to take up, based on the challenges named by school principals, that the competencies they mobilize are included in the competency standard, with the exception of emotional intelligence, previous teaching experience, managing stress and the unexpected. We note that six competencies identified by the participants are part of the professional competencies while four other competencies come from the transversal competencies domain of the Quebec competency standard. On the base of presented results, the competency standard of competencies needed for school principals (MELS, 2008) remains a reliable guide for initial training and for professional development of the school principals. In this case, principals and vice-principals acknowledge the competency standard and the fact that cross-curricular and professional competencies embody it. As a result, school principals have a good reference in order to be able to meet the challenges that face them in everyday school life.

However, it seems important to pursue a sequential reflection so that cross-curricular and professional competencies are developed sufficiently by school principals and vice-principals to be able to relieve challenges they can have in their function. By doing this, they must also keep in mind the ever-increasing expectations of society towards education and adapt (Boyer, Corriveau, \& Pelletier, 2009; Pont et al., 2008). Emotional intelligence, stress management and unforeseen events are examples of elements that would be interesting to the stakeholders since they are part of actual concerns.

This study contributes to the development of school principals' competencies useful in the day-to-day challenges and opens up different research opportunities. So, it would be useful to continue to explore the impact of the development of the school principals' competencies on their work and the challenges they face. This could be reflected in the study of the sense of effectiveness in meeting challenges through the development of school principals' competencies. It would also be interesting to analyse the forms of professional development used by school principals that help them to continue to prepare for the challenges they face in their work.

\section{References}

Archambault, J., Garon, R., \& Harnois, L. (2014). Diriger une école en milieu défavorisé: observation des pratiques de travail de directions d'école primaire de la région de Montréal. McGill Journal of Education, 49(2), 417-436.

Armstrong, D. (2009). Administrative passage: Navigating the transition from teacher to assistant principal. New York, New York: Springer.

Australian Institute for teaching and school leadership [AITSL]. (2015). Australian Professionnal Standard for Principal and the Leadership Profiles. Retrieved from https://www.aitsl.edu.au/docs/default-source/default-document-library/australian- 
professional-standard-for-principals-and-the-leadershipprofiles652c8891b1e86477b58fff00006709da.pdf?sfvrsn=11c4ec3c 2

Bandura, A. (1977). Social learning theory. Englewood Cliffs, Prentice Hall.

Bandura, A. (1986). Social foundations of thought and action: A social cognitive theory. Englewood Cliffs, NJ: Prentice-Hall.

Bandura, A. (2003). Auto-efficacité: Le sentiment d'efficacité personnelle. Paris: Éditions De Boeck.

Barber, M., \& Mourshed, M. (2007). How the world's best-performing schools come out on top. London: McKinsey \& Company.

Barber, M., Whelan, F., \& Clark, M. (2010). Capturing the leadership premium. How the world's top school systems are building leadership capacity for the future. London: McKinsey \& Company.

Barnabé, C., Toussaint, P. (2002). L'administration de l'éducation: Une perspective historique. Québec, Canada: Les Presses de l'Université du Québec.

Bernatchez, J. (2011). La formation des directions d'établissement scolaire au Québec: Apprendre à développer un savoir-agir complexe. Télescope, 17(3), 158-175.

Bisaillon, R., Inchauspé, P., Massé, D., Miron, D., Morin, S., \& Sauvageau, P. (2009). Un collectifpour l'éducation; l'école comme établissement d'enseignement et la réussite. De l'accessibilité à l'école à la réussite dans l'école. FQDE.

Boyer, M., Corriveau, L., \& Pelletier G . (2009). Des compétences en action: Référentiels et pratiques de formation pour des dirigeants de l'éducation. Revue Belge InDirect, 14, 21-36.

Brahimi, C. (2011). L'approche par compétences; un levier de changement des pratiques en santé publique au Québec. Québec: Institut national de santé publique du Québec.

Brassard, A. (1996). Conception des organisations et de la gestion. Montréal: Éditions Nouvelles.

Brassard, A. (2009). Référentiel de compétences et élaboration de programmes en gestion de l'éducation: «C'est un peu plus compliqué que ça». Dans M. Ettayebi, R. Opertti, \& P. Jonnaert, (pp. 237-252) Logique de compétences et développement curriculaire: débats, perspectives et alternative pour les systèmes éducatifs. Paris: L'Harmattan.

CERCLE. (1997). Termes révisés en vue de la 3e édition du Dictionnaire actuel de l'éducation. Montréal, Université du Québec à Montréal. Document inédit en administration de l'éducation.

Corriveau, L., Boyer, M., \& Fernandez, N. (2009). La qualité en éducation: Un enjeu de collaboration à cerner. La revue de l'innovation: La Revue de l'innovation dans le secteur public, 14(3), article 5 .

Corriveau, L. (2004). Identification professionnelle ou sur identification à la profession? La situation des directrices et des directeurs d'établissements scolaires québécois. Éducation et francophonie, XXX11(2), 95-110.

Darling-Hammond, L., Meyerson, D., LaPointe, M. \& Orr, M. T. (2010). Preparing principals for a changing world. San Francisco, CA: Jossey-Bass.

Davis, S., Darling-Hammond, L., LaPointe, M., \& Meyerson, D. (2005). Review of research, school leadership study: Developing successful principals. Palo Alto, CA: Stanford Educational Leadership Institute, Wallace Foundation.

Dembélé, M., Goulet, S., Lapointe, P., Deniger, M.-A., Giannas, V., \& Tchimou, M. (2013). Chapitre 4. Perspective historique de la construction du modèle québécois de gestion scolaire axée sur les résultats. In C. Maroy, L'école à l'épreuve de la performance; les politiques de régulation par les résultats (pp. 89-106). Bruxelles, Belgique: Éditions De Boeck.

Déry, S. (2004) Chapitre 2; les aspects juridiques de la gestion par résultats: imputabilité, reddition de comptes et responsabilisation. In L. Langlois \& C. LapointeGérer la réussite éducative: un processus responsable (pp. 39-69). Moncton, N-B.: Les éditions de la francophonie. 
Dufour, R., \& Eaker, R. (2004). Communautés d'apprentissage professionnelles. Méthodes d'amélioration du rendement scolaire. Bloomington, IN: National Education Service.

Dupuis, P. (2004). L'administration de l'éducation: quelles compétences? Education et francophonie, XXX11(2), 33-157.

Fédération québécoise des directions d'établissement d'enseignement [FQDE]. (2009). La bureaucratie et le leadership scolaire. Montréal, Québec: Fédération québécoise des directions d'établissement d'enseignement-FQDE.

Fortin, R. (2006). L'insertion professionnelle des nouvelles directions d'établissement d'enseignement. Montréal: FQDE.

Fullan, M. (2001). The new meaning of educational change ( $3^{\text {rd }}$ ed.) Toronto, Canada: Irwin Publishing.

Fullan. M. (2010). All systems goes: the change imperative for whole system reform. Thousand Oaks, CA: Corwin Press.

Fullan, M., \& Leithwood, K., (2012). Le leadership du XX1e siècle: se tourner vers l'avenir, IV(1). Retrieved from: http://www.edu.gov.on.ca/fre/policyfunding/leadership/fall2012Fr.pdf

Gerbé, O., Raynauld, J., \& Téta Nokam, N.M. (2012). Référentiels de compétences: De la conception à la mise en oeuvre. Congrès 2012 de l'Association internationale de pédagogie universitaire (actes du colloque), 181-189.

Goleman, D. (1997). L'intelligence émotionnelle, Paris: Robert Laffont.

Gravelle, F. (2012). Quels sont les principaux changements qui ont modifié la fonction de direction ou de direction adjointe d'établissement scolaire depuis l'avènement de la réforme de l'administration publique au Québec? Éducation et francophonie, 40(1), 76-93.

Guillemette, S., Morin, F., \& Simon, L. (2015). Une démarche de questionnement pour une gestion différenciée de l'activité éducative. Formation et profession, 23(3), 45-56.

Huberman, A. M., \& Miles, M. B. (1984). Qualitative data analysis: a sourcebook of new methods. Sage Publications.

Huberman, A. M., \& Miles, M. B. (1991). Analyse des données qualitatives. Bruxelles: Éditions de Boeck. Huberman, A. M., \& Miles, M. B. (1994). Data management and analysis methods. In N. K Denzin \& Y. S. Lincoln (Eds.), Handbook of qualitative research (pp. 428-444). London/New Delhi: SAGE Publications.

Ingvarson, L., Anderson, M., Gronn, P., \& Jackson, A. (2006). Standards for school leadership: A critical review of literature. Acton: Australian Institute for Teaching and School Leadership.

Jonnaert, P. (2005). Cadre théorique: curriculum de la formation générale de base, version provisoire. Direction de la formation générale des adultes. Ministère de l'Éducation, du Loisir et du Sport.

Jonnaert, P. (2009). Compétences et socioconstructivisme: Un cadre théorique. Bruxelles: Éditions de Boeck.

Langlois, L. (2004). Les défis éthiques qui sous-tendent la gestion axée par les résultats. In L. Langlois \& C. Lapointe, Gérer la réussite éducative: Un processus responsable (pp. 21-37). Moncton, N-B.: Les éditions de la francophonie.

Langlois, L. (2012). Le leadership éthique: Vecteur d'intégrité professionnelle. Retrieved from: http ://fncsf .ca/wp-content/uploads/ 2014/05/le-leadership-ethique .pdf

Lapointe, C., \& Gauthier, M. (2005). Le rôle de la direction d'école dans la dynamique de la réussite des élèves. In L. DeBlois \& D. Lamothe (Eds.), La réussite scolaire: Comprendre et mieux intervenir (pp. 39-50). Saint-Nicolas, Québec: Les Presses de l'Université Laval.

Le Boterf, G. (2000). La mise en place d'une démarche compétence: Quelques conseils de réussite. PERSONNEL, (412), 1-9.

Le Boterf, G. (2008). Repenser la compétence. Paris: Éditions d'Organisation.

Le Boterf, G. (2010). Construire les compétences individuelles et collectives (5e éd.). Paris: Éditions d'Organisation. 
Leclerc, M. (2012). Communautés d'apprentissage professionnelle: Guide à l'intention des leaders scolaires.

Boisbriand, Qc: Presses de l’Université du Québec.

Lecoeur, E. (2008). Gestion des compétences: Le guide pratique. Bruxelles, Belgique: Éditions de Boeck.

Legendre, R. (2005). Dictionnaire actuel de l'éducation (3e éd). Montréal: Guérin.

Leithwood, K., Day, C., Sammons, P., Harris, A., \& Hopkins, D. (2006). Seven strong claims about successful school leadership. Nottingham: NCSL/DfES Publications.

Leithwood, K., Louis, K. S., Anderson, S., \& Wahlstrom, K. (2004). How leadership influences student learning: Review of research. New York: Wallace Foundation.

Lenoir, Y. (2010). La notion de référentialité dans la formation à l'enseignement. Recherche et formation, 64, 91-104.

Lessard, C., Kamanzi, P. C. \& Larochelle, M. (2009). De quelques facteurs facilitant l'intensification de la collaboration au travail parmi les enseignants: Le cas des enseignants canadiens. Éducation et Société, 1(23), 59-77

Louis, K. S., Leithwood, K., Wahlstrom, K., \& Anderson, S. (2010). Investigating the links to improved student learning: Final report of research findings. New York: Wallace Foundation.

Maroy, C. (2013). Chapitre Introduction, Politiques et outils de «l'école de la performance»: Accountability, régulation par les résultats et pilotages. In M. Maroy, L'école à l'épreuve de la performance; les politiques de régulation par les résultats (pp. 13-31). Bruxelles: Éditions De Boeck.

Ministère de l'Éducation, du Loisir et du Sport [MELS]. (2008). La formation à la gestion d'un établissement scolaire: les orientations et les compétences professionnelles. Gouvernement du Québec.

Ministère de l'Éducation, du Loisir et du Sport [MELS]. (2006). Étude des pratiques de soutien et d'accompagnement des nouvelles directions d'établissement. Gouvernement du Québec.

Mulford, B. (2003). L'évolution des fonctions de directions en milieu scolaire et son incidence sur l'efficacité des enseignants et des établissements. OCDE.

Paquay, L. (1994). Vers un référentiel des compétences professionnelles de l'enseignant? Recherche et formation, (15), 7-38.

Parson, M. K. (2000). L'art de la communication efficace. Montréal: Les éditions internationales Alain Stanké.

Pelletier, G. (2001). La décentralisation du système scolaire québécois: Une variation sur un thème majeur. Éducation et francophonie, XX1X(2), 15-168.

Perrenoud, P. (1996). Enseigner: agir dans l'urgence, décider dans l'incertitude. Savoirs et compétences dans un métier complexe. Paris: ESF.

Perrenoud, P. (2002). Une formation réflexive et constructiviste des chefs d'établissement. Retrieved from:

https://www.unige.ch/fapse/SSE/teachers/pernoud/php main/php 2002/2002 11.html

Poirel, E., \& Yvon, F. (2011). Les sources de stress, les émotions vécues et les stratégies d'ajustement des directions d'école au Québec. Revue des sciences de l'éducation, 37(30), 595-615.

Poirel, E., Yvon, F., Lapointe, P., \& Denecker, C. (2017). La fonction de direction scolaire adjointe: Une comparaison des sources de stress entre adjoints et directions. Revue des sciences de l'éducation, 43(2), 231-260.

Pont, B. (2013). Learning standards, teaching standards and standards for school principals: A comparative study (Rapport no. EDU/WKP(2013)14). Centre of Study for Policies and Practices in Education (CEPPE), Chili: Organisation de coopération et de développement économiques (OCDE).

Pont, B., Nusche, N., \& Moorman, H. (2008). Améliorer la direction des établissements scolaires. Volume 1: Politiques et pratiques. OCDE. Retrieved from http://www.oecd.org/fr/education/scolaire/44374906.pdf 
Rey, B. (2006). Les compétences professionnelles et le curriculum: des réalités conciliables? In Y. Lenoir \& M.-H. Bouillier-Oudot (Dir.), Savoirs professionnels et curriculum de formation (pp. 83107). Québec, Canada: Les Presses de l'université Laval.

Scheerens, J. (2016). Educational effectiveness and ineffectiveness: A critical review of the knowledge base. Dordrechr, Pays-Bas: Springer.

Tardif, J. (2006). L'évaluation des compétences: Documenter le parcours de développement. Montréal: Chenelière Éducation.

Trudeau, J. (2013). L'organisation et l'actualisation de la gestion axée sur les résultats au sein des établissements scolaires. Mémoire. Rimouski, Québec, Université du Québec.

United Nations Educational, Scientific and Cultural Organization [UNESCO]. (2006). Les nouveaux rôles des chefs d'établissement dans l'enseignement secondaire. Paris, France. Organisation des Nations Unies pour l'éducation, la science et la culture.

Van der Maren, J. M. (2004). Méthodes de recherche pour l'éducation (2nd ed.). Bruxelles: Éditions Le Boeck.

Weisinger, H. (2005). L'intelligence émotionnelle au travail. Montréal: Les éditions Transcontinental. 


\section{Appendix 1}

\section{The Quebec Competency Standard (2008)}

\section{LES COMPÉTENCES PROFESSIONNELLES REQUISES POUR LA GESTION D'UN ÉTABLISSEMENT D'ENSEIGEMENT}

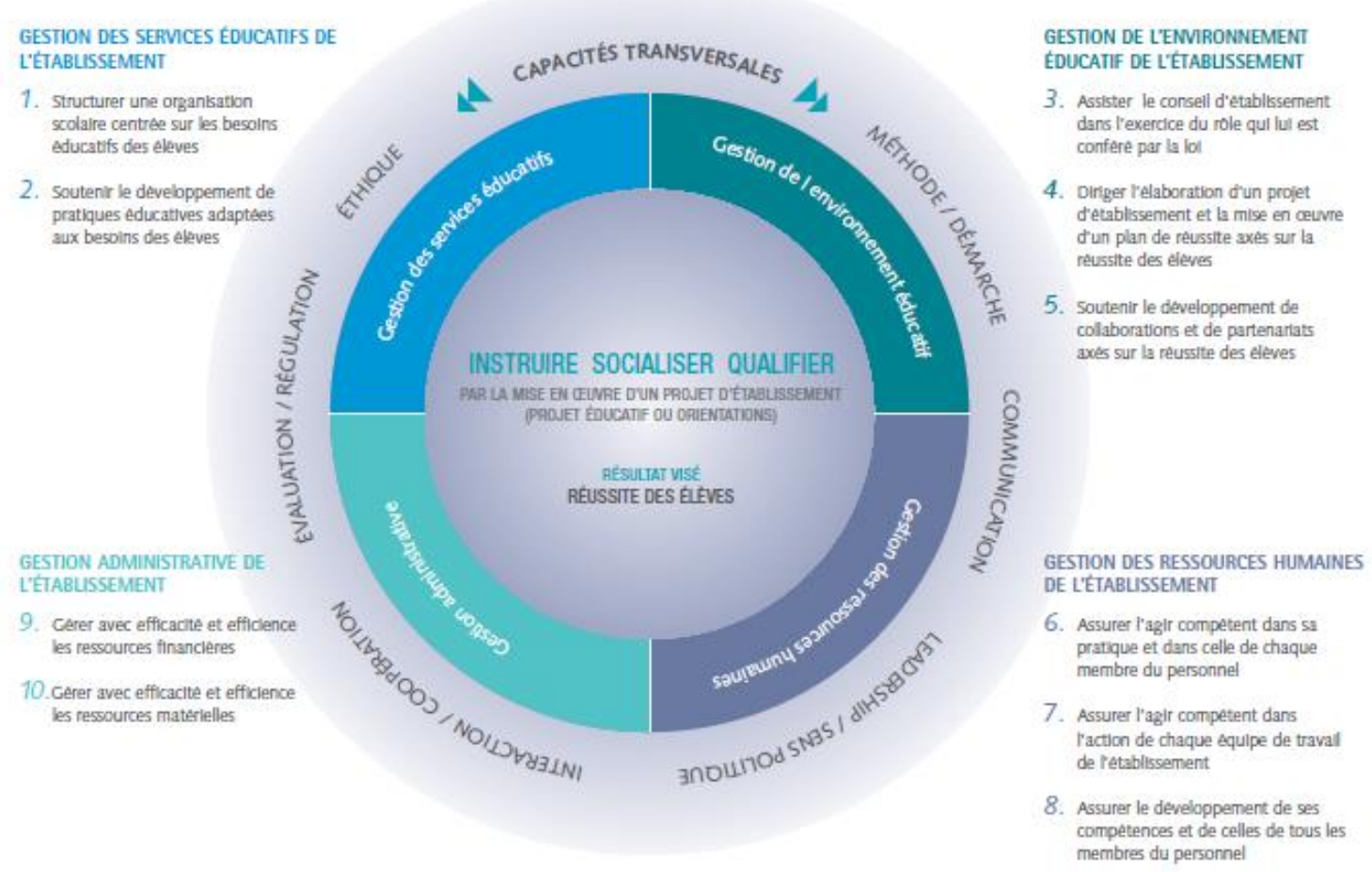




\title{
About the Authors
}

\section{Monique Lambert}

Université Laval (Québec, Canada)

monique.lambert.2@ulaval.ca

Monique Lambert was a School Principal and is currently pursuing Doctoral Studies in

Education, more specifically in Educational Administration and Policy.

\section{Yamina Bouchamma}

Université Laval (Québec, Canada)

yamina.bouchamma@fse.ulaval.ca

Yamina Bouchamma is a Professor in the Department of Foundations and Practices in the Faculty of Education.

\section{About the Guest Editors}

\author{
Augusto Riveros \\ Western University \\ gus.riveros@uwo.ca \\ ORCID: http://orcid.org/0000-0002-9942-6380
}

Augusto Riveros is associate professor in critical policy equity and leadership studies in the Faculty of Education at Western University in Ontario. Canada. His areas of interest include methods and theory in educational administration and leadership, policy analysis and education reform. His work has been published in numerous international journals and edited books. Dr. Riveros' research has been supported by the Social Sciences and Humanities Research Council of Canada (SSHRC).

\section{Wei Wei}

Western University

wwei32@uwo.ca

ORCID: http://orcid.org/0000-0002-0090-5614

Wei Wei is a Ph.D. Candidate in critical policy, equity, and leadership studies in the Faculty of Education at Western University in Ontario Canada. Her research interests include educational leadership, policy analysis, and comparative and international education. 


\title{
Special Issue \\ Standards and Competency Frameworks for School Administrators: Global, Comparative and Critical Perspectives
}

\section{education policy analysis archives}

\author{
Volume 27 Number $116 \quad$ September 23, 2019
}

ISSN 1068-2341

\section{(c) () (9)}

Readers are free to copy, display, distribute, and adapt this article, as long as the work is attributed to the author(s) and Education Policy Analysis Archives, the changes are identified, and the same license applies to the derivative work. More details of this Creative Commons license are available at https://creativecommons.org/licenses/by-sa/2.0/. EPAA is published by the Mary Lou Fulton Institute and Graduate School of Education at Arizona State University Articles are indexed in CIRC (Clasificación Integrada de Revistas Científicas, Spain), DIALNET (Spain), Directory of Open Access Journals, EBSCO Education Research Complete, ERIC, Education Full Text (H.W. Wilson), QUALIS A1 (Brazil), SCImago Journal Rank, SCOPUS, SOCOLAR (China).

Please send errata notes to Audrey Amrein-Beardsley at audrey.beardsley@asu.edu

Join EPAA's Facebook community at https://www.facebook.com/EPAAAAPE and Twitter feed@epaa_aape. 


\section{education policy analysis archives editorial board}

Lead Editor: Audrey Amrein-Beardsley (Arizona State University)

Editor Consultor: Gustavo E. Fischman (Arizona State University)

Associate Editors: Melanie Bertrand, David Carlson, Lauren Harris, Eugene Judson, Mirka Koro-Ljungberg,

Daniel Liou, Scott Marley, Molly Ott, Iveta Silova (Arizona State University)

Cristina Alfaro

San Diego State University

Gary Anderson

New York University

Michael W. Apple

University of Wisconsin, Madison

\section{Jeff Bale}

University of Toronto, Canada

Aaron Bevanot SUNY Albany

David C. Berliner

Arizona State University

Henry Braun Boston College

\author{
Casey Cobb \\ University of Connecticut \\ Arnold Danzig \\ San Jose State University \\ Linda Darling-Hammond \\ Stanford University \\ Elizabeth H. DeBray \\ University of Georgia \\ David E. DeMatthews \\ University of Texas at Austin \\ Chad d'Entremont Rennie Center \\ for Education Research \& Policy \\ John Diamond \\ University of Wisconsin, Madison \\ Matthew Di Carlo \\ Albert Shanker Institute \\ Sherman Dorn \\ Arizona State University \\ Michael J. Dumas \\ University of California, Berkeley \\ Kathy Escamilla \\ University ofColorado, Boulder \\ Yariv Feniger Ben-Gurion \\ University of the Negev \\ Melissa Lynn Freeman \\ Adams State College \\ Rachael Gabriel \\ University of Connecticut
}

Amy Garrett Dikkers University

of North Carolina, Wilmington

Gene V Glass

Arizona State University

Ronald Glass University of

California, Santa Cruz

Jacob P. K. Gross

University of Louisville

Eric M. Haas WestEd

Julian Vasquez Heilig California State University, Sacramento

Kimberly Kappler Hewitt

University of North Carolina

Greensboro

Aimee Howley Ohio University

Steve Klees University of Maryland

Jaekyung Lee SUNY Buffalo

Jessica Nina Lester

Indiana University

Amanda E. Lewis University of

Illinois, Chicago

Chad R. Lochmiller Indiana

University

Christopher Lubienski Indiana

University

Sarah Lubienski Indiana University

William J. Mathis

University of Colorado, Boulder

Michele S. Moses

University of Colorado, Boulder

Julianne Moss

Deakin University, Australia

Sharon Nichols

University of Texas, San Antonio

Eric Parsons

University of Missouri-Columbia

Amanda U. Potterton

University of Kentucky

Susan L. Robertson

Bristol University
Gloria M. Rodriguez

University of California, Davis

R. Anthony Rolle

University of Houston

A. G. Rud

Washington State University

Patricia Sánchez University of

University of Texas, San Antonio

Janelle Scott University of

California, Berkeley

Jack Schneider University of

Massachusetts Lowell

Noah Sobe Loyola University

Nelly P. Stromquist

University of Maryland

Benjamin Superfine

University of Illinois, Chicago

Adai Tefera

Virginia Commonwealth University

A. Chris Torres

Michigan State University

Tina Trujillo

University of California, Berkeley

Federico R. Waitoller

University of Illinois, Chicago

Larisa Warhol

University of Connecticut

John Weathers University of

Colorado, Colorado Springs

Kevin Welner

University of Colorado, Boulder

Terrence G. Wiley

Center for Applied Linguistics

John Willinsky

Stanford University

Jennifer R. Wolgemuth

University of South Florida

Kyo Yamashiro

Claremont Graduate University

Miri Yemini

Tel Aviv University, Israel 


\section{archivos analíticos de políticas educativas consejo editorial}

Editor Consultor: Gustavo E. Fischman (Arizona State University)

Editores Asociados: Felicitas Acosta (Universidad Nacional de General Sarmiento, Argentina), Armando Alcántara Santuario (Universidad Nacional Autónoma de México), Ignacio Barrenechea, Jason Beech (Universidad de San Andrés), Angelica Buendia, (Metropolitan Autonomous University), Alejandra Falabella (Universidad Alberto Hurtado, Chile), Veronica Gottau (Universidad Torcuato Di Tella), Antonio Luzon, (Universidad de Granada), José Luis Ramírez, (Universidad de Sonora), Paula Razquin, Axel Rivas (Universidad de San Andrés), Maria Alejandra Tejada-Gómez (Pontificia Universidad Javeriana, Colombia)

Claudio Almonacid

Universidad Metropolitana de

Ciencias de la Educación, Chile

\section{Miguel Ángel Arias Ortega \\ Universidad Autónoma de la \\ Ciudad de México}

Xavier Besalú Costa

Universitat de Girona, España

Xavier Bonal Sarro Universidad

Autónoma de Barcelona, España

Antonio Bolívar Boitia

Universidad de Granada, España

José Joaquín Brunner Universidad Diego Portales, Chile

Damián Canales Sánchez Instituto Nacional para la Evaluación de la Educación, México

Gabriela de la Cruz Flores

Universidad Nacional Autónoma de México

Marco Antonio Delgado Fuentes

Universidad Iberoamericana,

México

Inés Dussel, DIE-CINVESTAV, México

Pedro Flores Crespo Universidad Iberoamericana, México

\section{Ana María García de Fanelli \\ Centro de Estudios de Estado y \\ Sociedad (CEDES) CONICET, Argentina \\ Juan Carlos González Faraco \\ Universidad de Huelva, España \\ María Clemente Linuesa \\ Universidad de Salamanca, España \\ Jaume Martínez Bonafé \\ Universitat de València, España}

Alejandro Márquez Jiménez

Instituto de Investigaciones sobre la Universidad y la Educación, UNAM, México

María Guadalupe Olivier Tellez, Universidad Pedagógica Nacional, México

Miguel Pereyra Universidad de Granada, España

Mónica Pini Universidad Nacional de San Martín, Argentina

Omar Orlando Pulido Chaves Instituto para la Investigación Educativa y el Desarrollo Pedagógico (IDEP) José Ignacio Rivas Flores Universidad de Málaga, España

\author{
Miriam Rodríguez Vargas \\ Universidad Autónoma de \\ Tamaulipas, México \\ José Gregorio Rodríguez \\ Universidad Nacional de Colombia, \\ Colombia \\ Mario Rueda Beltrán Instituto de \\ Investigaciones sobre la Universidad \\ y la Educación, UNAM, México \\ José Luis San Fabián Maroto \\ Universidad de Oviedo, \\ España
}

Jurjo Torres Santomé, Universidad de la Coruña, España

Yengny Marisol Silva Laya

Universidad Iberoamericana, México

Ernesto Treviño Ronzón

Universidad Veracruzana, México

Ernesto Treviño Villarreal

Universidad Diego Portales

Santiago, Chile

Antoni Verger Planells

Universidad Autónoma de

Barcelona, España

Catalina Wainerman

Universidad de San Andrés, Argentina

Juan Carlos Yáñez Velazco

Universidad de Colima, México 


\section{arquivos analíticos de políticas educativas conselho editorial}

Editor Consultor: Gustavo E. Fischman (Arizona State University)

Editoras Associadas: Kaizo Iwakami Beltrao, (Brazilian School of Public and Private Management - EBAPE/FGV, Brazil), Geovana Mendonça Lunardi Mendes (Universidade do Estado de Santa Catarina), Gilberto José Miranda, (Universidade Federal de Uberlândia, Brazil), Marcia Pletsch, Sandra Regina Sales (Universidade Federal Rural do Rio de Janeiro)

\author{
Almerindo Afonso \\ Universidade do Minho \\ Portugal \\ Rosanna Maria Barros Sá \\ Universidade do Algarve \\ Portugal \\ Maria Helena Bonilla \\ Universidade Federal da Bahia \\ Brasil \\ Rosa Maria Bueno Fischer \\ Universidade Federal do Rio Grande \\ do Sul, Brasil

\begin{abstract}
Alice Casimiro Lopes
Universidade do Estado do Rio de

Janeiro, Brasil
\end{abstract}

\section{Suzana Feldens Schwertner \\ Centro Universitário Univates} \\ Brasil \\ Flávia Miller Naethe Motta \\ Universidade Federal Rural do Rio de \\ Janeiro, Brasil
}

\section{Alexandre Fernandez Vaz \\ Universidade Federal de Santa \\ Catarina, Brasil}

\section{Regina Célia Linhares Hostins \\ Universidade do Vale do Itajaí, Brasil}

\section{Alfredo Macedo Gomes \\ Universidade Federal de Pernambuco \\ Brasil}

\section{Jefferson Mainardes}

Universidade Estadual de Ponta

Grossa, Brasil

\section{Jader Janer Moreira Lopes \\ Universidade Federal Fluminense e \\ Universidade Federal de Juiz de Fora, Brasil \\ Debora Nunes \\ Universidade Federal do Rio Grande do Norte, Brasil}

\section{Alda Junqueira Marin \\ Pontifícia Universidade Católica de São Paulo, Brasil}

\section{Dalila Andrade Oliveira}

Universidade Federal de Minas

Gerais, Brasil
José Augusto Pacheco

Universidade do Minho, Portugal

Jane Paiva

Universidade do Estado do Rio de

Janeiro, Brasil

Paulo Alberto Santos Vieira

Universidade do Estado de Mato

Grosso, Brasil

Fabiany de Cássia Tavares Silva

Universidade Federal do Mato

Grosso do Sul, Brasil

António Teodoro

Universidade Lusófona

Portugal

\section{Lílian do Valle}

Universidade do Estado do Rio de Janeiro, Brasil

\section{Alfredo Veiga-Neto}

Universidade Federal do Rio Grande do Sul, Brasil 